ISSN 1979-5572 (print) | ISSN 2541-6480 (online)

http://ejurnal.iainpare.ac.id/index.php/kuriositas

\title{
KURIOSITAS
}

Media Komunikasi Sosial dan Keagamaan

\begin{tabular}{lll}
\hline Volume 13 & No.1, Juni 2020 & Halaman 103 - 124 \\
\hline
\end{tabular}

\section{Peran Strategis IAIN Ambon dan IAKN Ambon Dalam Merawat Toleransi Sosial dan Moderasi Beragama di Ambon Maluku}

\author{
Mahyuddin', Rustam Magun Pikahulan'2, Muhammad Fajar ${ }^{3}$ \\ 1,2,3Institut Agama Islam Negeri Parepare, \\ rustammagunpikahulan@iainpare.ac.id,muhammadfajar@iainpare.ac.id \\ mahyuddin@iainpare.ac.id
}

\begin{abstract}
Tolerance and moderation in Indonesia are the discourses that have been much discussed lately. The government, community leaders including educational institutions are very active campaigning for these narrative. This study aims to describe the role of State Islamic Institute of Ambon (IAIN Ambon) and State Christian Institute of Ambon (IAKN Ambon) in preserving social tolerance and religious moderation. This article used qualitative research method by using case study. The authors collected data through interviews, observation, and documentation. The results of this study indicated that the consequences of past religious conflicts effect social tolerance and religious moderation in society. However, this threat can be dechipered by the two religius institutions by providing assistance and guidance to the wider community about the impotance of preserve harmony in diversity. In an effors to break down differences and antagonisms in society, Amobenese people were increangsingly being transformed into "harmony life" and out of the conditions of "suspicion and hostility" even though the relationship of religious groups still holds the strong potential for repeated social friction involving two religious groups.
\end{abstract}

Keyword: Social Intolerance, Religious Moderation, IAIN and IAKN, Ambon 


\begin{abstract}
ABSTRAK
Toleransi dan moderasi di Indonesia merupakan suatu diskursus yang akhirakhir ini begitu banyak diperbincangkan. Pemerintah, tokoh-tokoh masyarakat, tidak terkecuali lembaga-lembaga pendidikan sangat aktif membangun narasi tersebut. Penelitian ini bertujuan untuk menggambarkan peran Institut Agama Islam Negeri (IAIN) Ambon dan Institut Agama Kristen Negeri (IAKN) Ambon dalam merawat toleransi sosial dan moderasi beragama. Artikel ini menggunakan metode penelitian kualitatif dengan jenis penelitian studi kasus. Penulis mengumpulkan data melalui wawancara, observasi dan dokumentasi. Hasil penelitian ini menunjukkan bahwa konsekuensi konflik agama masa lalu memengaruhi toleransi sosial dan moderasi beragama dalam masyarakat. Namun, ancaman ini dapat diurai oleh kedua lembaga pendidikan tinggi keagamaan dengan melakukan pendampingan dan pembimbingan kepada masyarakat luas tentang pentingnya merawat keharmonian dalam perberbedaan. Dalam upaya meretas perbedaan dan antagonisme di dalam masyarakat, masyarakat Ambon semakin terbuka diubah menjadi "kerukunan hidup" dan keluar dari dunia "kecurigaan dan permusuhan" meskipun hubungan kelompok-kelompok penganut agama masih menyimpan potensi kuat berulangnya gesekan sosial yang melibatkan dua kelompok agama.
\end{abstract}

Kata kunci: Toleransi Sosial, Modoresi Beragama, IAIN dan IAKN, Ambon. PENDAHULUAN

Secara sosiohistoris, Ambon merupakan sebuah kota yang pernah diliputi konflik sosial keagamaan. Fakta sejarah mencatat bahwa konflik disertai aksi kekerasan yang terjadi di Ambon Maluku tahun 1999-2002 merupakan salah satu konflik agama yang pahit di Indonesia. Perpecahan antara komunitas Islam dan Kristen dalam lingkup kehidupan masyarakat secara luas telah bermuara pada wajah kekerasan (Cooper 2011). Konflik yang dipicu oleh konflik interpersonal tersebut meluas menjadi konflik etnis religius yang menghancurkan tatanan sosial, ekonomi bahkan politik masyarakat Ambon (Susan 2009).

Pasca reformasi perkembangan kehidupan sosial antarumat beragama di kota Ambon mengalami pasang surut. Masih bersemainya benih-benih konflik di benak masyarakat memunculkan ketegangan sosial berkepanjangan. Segregasi sosial yang timbul di masyarakat sedikit 
banyak telah dipengaruhi oleh konstelasi konflik agama yang mengerus toleransi sosial dan moderasi beragama dalam masyarakat. Hubungan sosial lintas umat beragama memunculkan segregasi sosial yang ditandai dengan adanya pengkotak-kotakan kelompok (Hamid 2015). Hal ini yang memengaruhi konstelasi hubungan Islam dan Kristen di level akar rumput di mana masih kerap terjadi ketegangan hubungan antar kelompok agama yang mengancam kebersamaan umat dan keharmonisan sosial bersama.

Setelah konflik berkecamuk, masyarakat cenderung ekstrem dalam mengelola kemajemukan. Berbagai penelitian menunjukkan bahwa hubungan antar elemen masyarakat yang berbeda agama, mulai tersekat dalam hal interaksi dan cenderung menutup diri, ketiadaan kerja sama serta merebaknya gesekan kelompok (Manuputty 2014), (Lindawaty 2016), (Ichwanuddin 2016). Hal ini memicu ketegangan sosial antar kelompok agama sehingga ikhtiar untuk merawat keserasian sosial dan menyemai kebersamaan kedua belah pihak kelompok mulai tertutup. Kelompokkelompok agama seolah menutup ruang penghargaan atas pluralistas atau keragaman.

Namun demikian, semakin ke sini semakin terlihat bahwa konflik horizontal antara dua komunitas agama besar di Ambon menunjukkan tren positif ke arah konsolidasi. Sejak disepakatinya Perjanjian Malino yang menyepakati bersama untuk mengakhiri konflik, telah memutus mata rantai pertentangan masyarakat dan membawa pesan kegembiraan dalam upaya membangun dan mengelola keberagaman yang ideal di Ambon (Ernas 2012). Kehidupan masyarakat Maluku setelah konflik usai, menunjukkan bahwa polarisasi isu agama tidak lagi menonjol dibandingkan beberapa periode sebelum konflik (Pamungkas 2014). 
Bahkan Badan Pusat Statistik Nasional mencatat Provinsi Maluku menempati nomor dua pada nilai indeks kebahagiaan tahun 2017 berdasarkan hasil survei pengukuran tingkat kebahagiaan, sebuah indeks komposit yang disusun oleh tiga dimensi yaitu kepuasan hidup, perasaan dan makna hidup (Soplanit 2019).

Yang menarik dan penting adalah Institut Agama Islam Negeri (IAIN) Ambon dan Institut Agama Kristen Negeri (IAKN) Ambon merupakan modal penting dalam membingkai harapan baru perdamaian tersebut. Keterlibatan kedua pendidikan tinggi keagamaan ini dalam percaturan menjaga keharmonisan umat beragama turut mendukung proses pembangunan perdamaian di Ambon. Kedua pendidikan tinggi tersebut memiliki posisi penting dan strategis sebab berperan aktif dalam usaha-usaha rekonsiliasi di masyarakat (Toisuta 2019).

Melalui lembaga Ambon Reconciliation and Meditiation Center (ARMC) yang dibentuk sejak tahun 2011, IAIN Ambon mengambil peran penting dalam pembangunan perdamaian. Kehadiran ARMC-IAIN Ambon dalam menjalankan berbagai programnya sebagai Pusat Rekonsiliasi dan Mediasi di Maluku telah memfasilitasi penguatan dan sosialisasi ide serta program perdamaian di masyarakat. melatih anak-anak muda menjadi "agen perubahan" dan memediasi konflik. Eksistensi lembaga ini juga membuka diri untuk bekerja sama dengan lembaga luar yang memiliki konsen yang sama dalam upaya merawat perdamaian (Administrator 2019). ARMC-IAIN Ambon bekerjasama dengan Canadian Embassy, kedutaan negara asal Kanada Amerika Serikat; CSRC UIN Syarif Hidayatullah Jakarta; dan PUSAD Universitas Paramadina serta Pemerintah Provinsi Maluku dalam program-program pendidikan merawat persatuan warga masyarakat. Mereka aktif melakukan advokasi-advokasi pendidikan perdamaian dan kegiatan sosial keagamaan bernuansa kampanye toleransi dan moderasi, sebuah wadah perjumpaan antar lintas kelompok agama yang turut memengaruhi terciptanya kohesi sosial antara umat Islam dan Kristen. 
Tidak hanya IAIN Ambon, IAKN Ambon juga membangun peran-peran yang sama dengan mengadvokasi masyarakat dalam mensosialisasikan pentingnya perdamaian. Berdirinya Pusat Studi antar Budaya dan Agama (PSaBA), misalnya, kampus ini menawarkan program-program yang menyasar masyarakat umum terutama yang berlatar belakang identitas sosial yang berbeda dalam mewujudkan toleransi beda agama. Dalam rangka pengelolaan keragaman dalam kemajemukan serta mempromosikan diri sebagai kampus "harmoni dalam perbedaan”, di beberapa kesempatan, PSaBA IAKN Ambon menggagas workshop sekolah multikulturalisme pemuda lintas agama. Ini merupakan salah satu strategi membangun kebersamaan dalam menjembatani perjumpaan dengan semua elemen masyarakat (IAKN Ambon 2019).

Dalam perspektif teori sosial, hal ini merupakan pendekatan multikulturalisme melalui peran lembaga sosial. Terlihat dengan jelas bahwa antara IAIN Ambon dan IAKN Ambon tidak hanya menyediakan forum alternatif pemuda-pemudi kota Ambon dalam merespons realitas bermasyarakat yang eksklusif, tetapi juga turut serta mendorong persaudaraan masyarakat secara umum dalam bingkai penguatan pendidikan multikultural dan pluralisme agama. Upaya-upaya ini memiliki peran signifikan bagi terpeliharanya semangat keberagaman di Maluku tanpa menafikan peran pemerintah dan stakeholder lainnya yang tidak pernah berhenti mengupayakan terbentuknya keharmonian sosial antar pemeluk agama di kota ini.

Kajian ini penting, mengingat belum banyak kajian terdahulu yang mengurai peran kolaborasi kedua kampus berbeda identitas secara agama di Maluku. Peran di atas menjadi diskursus penting dalam tulisan ini sebab mereka terus berupaya meletakkan landasasan model pengelolaam keberagaman dengan mengedepankan sikap-sikap toleran dan akomodatif dalam mengkampanyekan idealitas pengelolaan kemajemukan umat beragama. Kedua kampus tersebut memiliki orientasi bagaimana melahirkan keharmonian sosial dan keserasian sosial dengan terus berupa mengubah pandangan keberagamaan masyarakat yang eksklusif menjadi lebih inklusif dan pluralis. 
Dengan demikian, tulisan ini hendak menguraikan toleransi sosial di kota Ambon, praktik moderasi beragama di kota Ambon Maluku dan peran stategis antara IAIN Ambon dan IAKN Ambon dalam merawat toleransi dan moderasi dalam upaya mewujudkan harmoni beragama dalam masyarakat. Metode penelitian menggunakan paradigma deskriptif kualitatif dengan pendekatan studi kasus. Penulis berkonsentrasi detil pada peran IAIN Ambon dan IAKN Ambon dalam upaya memupuk integrasi sosial masyarakat Maluku melalui kampanye toleransi sosial dan moderasi beragama dengan mengkaji programprogram yang dicetuskan oleh kedua kampus tersebut. Tidak hanya itu, peneliti juga memperbandingkan kedua program yang telah dilakukan, yang diperkuat dengan wawancara dan menelaah berbagai sumber seperti buku, artikel jurnal, pemberitaan media massa kedua kampus tersebut serta media mainstream lainnya terkait perhatian perguruan tinggi keagamaan ini terhadap upaya menumbuhkembangkan pola pikir toleransi sosial dan moderasi beragama pada masyarakat Ambon-Maluku.

Pada sisi yang lain, peneliti menggali berbagai sumber riset tentang pandangan inklusifisme dan moderatisme yang dikembangkan di kampus ini. Peneliti melihat bahwa gagasan kebangsaan, konstruk pemikiran kritis, penanaman nilai-nilai multikulturalisme dan penyampaian pesan agama yang damai dan toleran serta penebaran cinta pada kemanusiaan (Suharto 2019), secara tidak langsung telah dijadikan orientasi oleh kedua lembaga pendidikan tinggi keagamaan tersebut.

\section{PEMBAHASAN}

\section{Rajutan Toleransi Sosial di Ambon-Maluku}

Secara sederhana toleransi merupakan penghargaan dan penghormatan terhadap perbedaan. Toleransi adalah sebuah kultur sosial yang dibangun sedemikian rupa oleh individu atau kelompok pada patokan yang bersedia dengan varian ajaran atau perbedaan dalam 
lingkungannya (Rengganiasih 2009). Menurut Kamus Besar Bahasa Indonesia, toleran memiliki makna bahwa seseorang bersikap menenggang (menghargai, membiarkan, membolehkan) pendirian (pendapat, pandangan, kepercayaan, kebiasaan, kelakuan dan sebagianya) yang berbeda atau bertentangan dengan pendirian sendiri (Indonesia 2008). Artinya, seseorang atau kelompok meskipun memiliki latar belakang identitas berbeda seperti warna kulit, golongan, suku maupun agama tetapi mampu menghadirkan sikap penghormatan dan penghargaan terhadap yang lain.

Toleransi sosial di kota Ambon adalah salah satu keberhasilan masyarakat dan berbagai elemen bangsa dalam pengelolaan keragaman. Harus diakui, bahwa fenomena sosial keagamaan masyarakat di kota Ambon pasca konflik agama adalah, tercipta ketidakharmonisan sosial. Dengan kata lain, terendap ancaman toleransi dan moderasi bagi masyarakat Ambon pasca konflik bernuansa identitas. Ini setidaknya dapat dilihat pada fenomena setiap kelompok agama terdapat sensitivitas yang tinggi dan kondisi historis benturan identitas kedua agama (Islam vs Kristen) yang saling memengaruhi sehingga sering menimbulkan terjadinya gesekan antar kelompok agama. Buntutnya, apabila terjadi pertikaian antar kelompok masyarakat sering kali melibatkan simbolsimbol agama (Wawancara, FW, 2020).

Hal seperti itu yang sering dialami oleh warga berdasarkan pengalaman informan. Gejolak konflik agama masa lalu memicu kerentanan intoleransi dan menciderai moderasi beragama sebab persoalan tersebut sering kali mengganggu ketentraman hidup dan dimensi keharmonian hidup beragama masyarakat. Di sini, kapasitas masyarakat yang berlatar belakang berbeda agama, memengaruhi 
dinamika kemajemukan mereka dalam kehidupan sosial sebab sangat rentan dengan gesekan-gesekan sosial atas nama identitas agama.

Namun, perpecahan-perpecahan yang sebelumnya terjadi secara perlahan telah berubah ke arah harmoni sosial. Terlihat dengan jelas bahwa pasca konflik tersebut, telah tumbuh keseimbangan, kesetaraan dan keadilan dalam kehidupan masyarakat yang termanifestasikan dalam serangkaian tindakan kultural, yang berorientasi pada perdamaian. Perekat kebersamaan masyarakat dibangun sedemikian rupa demi mewujudkan toleransi sosial (Wawancara, RS, 2020).

Semangat ini tumbuh sebab berbagai elemen masyarakat merespons perubahan dan dinamika masyarakat bernuansa identitas agama maupun entitas kebudayaan. Mereka menghidupkan kembali rasa persaudaraan dalam bingkai "pela gandong", yaitu sebuah transformasi budaya perdamaian yang mengembangkan usaha-usaha pertemuan lintas tokoh dan agama dengan tujuan meningkatkan penghargaan sosial terhadap kemajemukan terutama membangun relasi dan toleransi antar umat beragama di Ambon (Mualim, Awang, and Bakar 2014), (Masringor and Sugiswati 2017).

Pela gandong adalah salah satu jawaban atas warga Ambon di dalam melawan perubahan karakter masyarakat yang kadang kala menggerus semangat harmoni beragama. Perjumpaan kelompok-kelompok masyarakat yang dibingkai dalam ritual ini, boleh dikata melampaui tradisi agama dalam mengatasi ketegangan umat. Betapa tidak, semakin ke sini semakin nyata bahwa pertemuan-pertemuan semacam ini berperan besar dalam merawat toleransi sosial di mana spirit dalam budaya ini meneguhkan kesadaran kolektif dan menjaga harmonisasi masyarakat di Maluku (Bakri 2015), (Aponno 2017), (Malatuny and Patra Ritiauw 2018). 
Dalam perspektif multikulturalisme, hal ini merupakaan cara mengelola kekayaan kultural bersama. Langkah ini tentu saja merupakan sebuah arena bagi penyatuan masyarakat yang berbeda, yang oleh Irwan Abdullah disebut "kecerdasan lokal", yaitu perspektif lokal yang menjadi jawaban atas pertanyaan besar kerukunan dalam kehidupan bersama di abad ini yang semakin terancam (Mahyuddin 2017), (Jubba 2019), (Mahyuddin 2019b), (Mahyuddin 2019c). Mereka secara sadar berupaya mewujudkan terciptanya kesatupaduan terutama keharmonian dalam perbedaan.

Dalam kaitan ini, terlihat bahwa terendap toleransi di masyarakat yang melibatkan berbagai pihak. Pertentangan (konflik komunal sebelumnya) dilihat sebagai anasir budaya yang anomali, maka masyarakat mulai memprakarsai agar masyarakat Ambon selalu diarahkan kepada "kerukunan hidup" dan keluar dari jalan "jeratan kecurigaan dan permusuhan" yang selama ini menjadi masalah bersama. Dengan "kesadaran bersama", mereka telah menunjukkan tentang pentingnya merawat kebhinnekaan. Masyarakat mulai mengambil bagian dalam membuka kemungkinan bagi kedua kelompok yang selama ini bertikai untuk hidup berdampingan secara sentosa.

Masyarakat mengejawantahkan penghargaan sosial yang dapat dilihat dari sejauh mana kelompok-kelompok masyarakat tersebut mulai melakukan pengendalian diri dan membuka ruang dialog. Jawaban-jawaban toleransi sosial tersebut yang di terapkan pada berbagai arena sosial sehingga secara perlahan pemeluk dua komunitas agama di Ambon kembali merajut hubungan emosional, sosial terlebih lagi spiritual secara baik. Arah dan tujuannya tentu saja dalam rangka mewujudkan perdamaian, keadilan, persaudaraan sosial, anti konflik dan kekerasan serta diskriminatif dalam lingkup kehidupan masyarakat (Ibrahim 2008), (Susanto et al. 2020).

Inilah manifestasi toleransi sosial yang terus dikembangkan oleh masyarakat Ambon. Mereka mencari titik-titik temu dalam rangka menjaga 
kondisi ideal umat beragama, yaitu mengharapkan kehidupan umat yang harmonis dengan saling mengakui dan menyadari pluralitas (Hayat 2012). Dalam kondisi ini, telah tumbuh dalam masyarakat tuntutan saling menghargai, saling menghormati, bahkan terbuka untuk berdialog dan bekerja sama untuk hal-hal konkrit sehingga semakin tumbuh rajutan toleransi sosial. Prinsipnya, telah tercipta dalam masyarakat semangat menumbuhkembangkan sikap apresiatif dalam menghadapi heterogenitas terutama dalam hal agama dalam lingkup kehidupan bersama.

\section{Prospek Moderasi Beragama Masyarakat di Masa Kini}

Bila membaca masa lalu konflik di kota Ambon, sesungguhnya ancaman moderasi beragama di masyarakat amatlah akut. Mengapa? Sebab bersemai dengan subur eksklusivisme di masyarakat yang memicu konflik agama. Itu terlihat pada pola segregasi antara umat Islam dan Kristen yang telah eksis dalam masyarakat Ambon. Di Maluku, sejak dari Pulau Morotai dan Halmahera di Maluku Utara sampai dengan pulaupulau Kai dan Tinambar di Maluku Tenggara, masyarakat bertempat tinggal secara eksklusif, berkelompok menurut suku dan agama (Hayat 2012). Segregasi sosial ini dapat dilihat secara geografis pembagian wilayah kedua komunitas tersebut di mana sangat jarang kedua komunitas agama, seperti desa atau kelurahan kelompok agama yang hidup berdampingan. Di tingkat desa atau kelurahan dengan mudah ditemukan apa yang disebut kampung Islam dan kampung Kristen (Susan 2009).

Kondisi-kondisi di atas itulah yang memengaruhi kondisi keharmonian sosial masyarakat terutama bagaimana mengelola kemajemukan umat beragama atau pluralisme agama. Dalam banyak hal, masing-masing kelompok agama tersegmentasi ke dalam kelompok masyarakat Islam dan kelompok masyarakat Kristen. Situasi tersebut yang 
membuat prospek moderasi beragama kala itu tergerus, terutama pengelolaan hubungan antara Islam dan Kristen. Melihat kondisi yang terjadi, kenyataan semacam ini memiliki benang merah menjadi persoalan intoleransi sosial dan sebagian lainnya menjadi persoalan hubungan antar umat beragama yang berkorelasi kuat terhadap memudarnya moderasi itu sendiri (Ahnaf, M. Iqbal \& Salim 2017), (Mahyuddin 2018), (Mahyuddin 2019a).

Tetapi, ada secercah harapan dalam melihat kondisi masyarakat Ambon saat ini. Itu karena perjumpaan-perjumpaan kelompok masyarakat dan lembaga sosial antar iman dalam mewujudkan moderasi beragama kian mengemuka. Betapa tidak, penguatan ideologi toleransi bahkan moderasi untuk menanggulangi tindakan-tindakan ekstremis berbalut keagamaan di Ambon, kini tengah gencar dilakukan. Dalam pergumulan kehidupan masyarakat, mereka berkehendak penuh untuk menciptakan model dan pemahaman agama yang inklusif, yaitu bersikap adil dan berimbang dalam merespons perbedaan bernuansa identitas yang termanifestasikan dalam serangkaian tindakan kultural berorientasi pada upaya menanamkan nilai dasar moderasi itu sendiri.

Sebagai contoh misalnya adalah kerjasama lintas iman dan organisasi keagamaan pada perhelatan Musabaqah Tilawatil Quran (MTQ), umat Kristiani di Ambon berpartisipasi dalam penyediaan akomodasi peserta. Sebaliknya, selama festival kor gereja nasional, beberapa sekolah Muslim berpartisipasi dengan mengirimkan tim kor untuk menampilkan beberapa lagu Maluku (Ode 2015). Di sini sangatlah jelas bahwa terdapat penguatan dan penataan dalam hubungan antar agama yang sesungguhnya diikuti dengan penguatan ideologi moderasi. Mengapa? Sebab dalam upaya-upaya tersebut secara tidak langsung telah dikonstruksi muatan pemahaman tentang toleransi antara umat beragama 
secara khusus dan moderasi beragama secara umum. Persilangan antar kelompok, organisasi serta tokoh-tokoh agama dalam kerjasama tersebut, menunjukkan bahwa mereka tidak lagi ekstrem dalam beragama sebab mereka senantiasa mengambil jalan tengah melihat titik perbedaan.

Kolaborasi yang dilakukan antar elemen masyarakat dalam perhelatan ini, menjadi alternative untuk memutus mata rantai konflik bernuansa agama di dalam kehidupan masyarakat. Para stakeholder yang terlibat di dalamnya demikian menyadari perlunya tampil di depan publik atau menunjukkan tindakan nyata tentang pentingnya menjaga keharmonian sosial, menyerasikan pencapaian persatuan, serta memelihara keragaman dalam perbedaan terutama menghindari gesekan agama. Itu terlihat pada tiga hal; Pertama, organisasi keagamaan menjadi basis perdamaian antara Islam dan Kristen. Kedua, memutus penyekat dengan bekerjasama dan saling tukar informasi terkait peringatanperingatan seremonial keagamaan. Ketiga, membuka ruang relasi yang intim untuk membongkar kecurigaan yang selama ini menjadi batas pemisah dua komunitas agama

Ini bukanlah kolaborasi sekali dilaksanakan kedua kelompok keagamaan di kota Ambon. Berbagai kegiatan semacam ini sudah sering dilangsungkan. Dalam banyak hal, kegiatan semacam ini tidak hanya melibatkan akademisi dan intelektual lainnya, tetapi juga tokoh-tokoh masyarakat dan pemuda pro-perubahan dalam proses penciptaan dan pergumulan toleransi sosial dan moderasi beragama. Kerjasama lintas iman tersebut prinsipnya memfasilitasi pentingnya merajut sikap saling mengasihi sesama, menghargai lokalitas serta terciptanya ruang publik sebagai ruang interaksi umat. Terlepas seseorang berbeda secara agama.

Inilah prospek moderasi beragama di kota Ambon yang kini mulai tumbuh. Masyarakat menyadari pentingnya keselarasan sosial antar umat beragama dengan berkomitmen menanggalkan semua kepentingan 
pribadi masyarakat yang sempit demi tercapainya keharmonisan sosial sesama umat beragama (Bedong et al. 2020). Singkatnya, harapanharapan untuk keadilan dan perdamaian telah dikolaborasikan oleh kedua kelompok agama secara sadar. Semaian tersebut merupakan dorongan bagi setiap insan untuk menyadari pentingnya merawat moderasi beragama dalam rangka membangun kohesivitas sosial masyarakat di Maluku di mana hal ini sangat efektif untuk merekatkan kembali masyarakat yang selama ini terbelah secara identitas.

Upaya tersebut di atas merupakan suatu terobosan penting mengingat hubungan kelompok-kelompok penganut agama di kota Ambon masih berpotensi mengalami gesekan sosial yang melibatkan dua kelompok agama (Muis 2020). Apalagi jika membaca peta sosial hubungan agama masyarakat masa kini seperti penelitian yang dilakukan oleh Irwan Abdullah. Bahwa masih kerap terjadi peningkatan ketegangan hubungan antarkelompok agama di beberapa daerah. Menyeruak di permukaan, hubungan antara Islam dan Kristen yang kontestatif dalam banyak wajah dan kondisi (Jubba 2019). Ini dipertegas juga dengan hasil riset Ahnaf dan Salim bahwa sering kali muncul kelompok-kelompok masyarakat bernuansa identitas yang berupaya mengubah tatanan sosial politik terutama dasar untuk mengatur kehidupan publik yang dianggap tidak memerhatikan standar ideal keagamaan tertentu (Ahnaf, M. Iqbal \& Salim 2017).

Namun demikian, hadirnya berbagai kerjasama antar elemen keagamaan dan organisasi sosial lainnya di lingkup kehidupan sosial, memberi ruang yang terbuka bagi tumbuhnya moderasi beragama, yaitu kondisi-kondisi ini memberi keseimbangan hubungan antar agama dalam masyarakat sebab kedua belah fihak mulai meruntuhkan tembok-tembok 
pemisah yang eksklusif menuju perjumpaan-perjumpaan yang inklusif. Atau populer disebut merangkul pihak yang selama ini terperosok dalam radikalisme dan ekstremisme ke arah perdamaian yang berkesinambungan (Saidurrahman 2019), (Mujahidin 2019), (Mahyuddin, Ilham, and Rusdi 2020).

\section{Peran IAIN dan IAKN dalam Pembangunan Toleransi dan Moderasi Beragama}

Tersemainya toleransi sosial dan moderasi di kota Ambon bukanlah sebuah perkara mudah. Tidak mudah untuk sampai pada di titik ini di mana dibutuhkan strategi-strategi keterlibatan berbagai pihak untuk menemukan resolusi konflik (Ode 2015). Penting diingat, di tengah deraan konflik yang pilu dan menyengsarakan seperti telah disinggung di atas, ketika banyak orang terjebak dan "terpaksa" terlibat secara langsung atau tidak dalam amuk konflik, tidak sedikit anak Maluku yang dengan caranya masing-masing mengambil jarak dan bersikap kritis terhadap konflik - dan, bersamaan dengan itu, berusaha memperjuangkan perdamaian (Manuputty 2014). Institut Agama Islam Negeri Ambon dan Institut Agama Kristen Negeri Ambon merupakan bagian dari bibit tempat bersemainya harapan baru perdamaian tersebut. Keterlibatan kedua pendidikan tinggi keagamaan ini dalam percaturan menjaga keharmonisan umat beragama, memiliki peran sangat penting dan strategis (Toisuta 2019).

Dalam konteks ini, IAIN Ambon dan IAKN Ambon turut mengambil peran besar dalam menyemai toleransi sosial dan moderasi beragama. Kedua institusi ini boleh dikata telah menjadi laboratorium toleransi sosial dan moderasi beragama, yaitu mereka memiliki titik perhatian yang sama pada pentingnya perdamaian tanpa mengesampingkan agama di Ambon. Dibentuknya lembaga AMRC dan 
PsbA, misalnya, hal ini merupakan suatu kehendak untuk mengembangkan kajian-kajian dalam rangka menguatkan narasi kebangsaan, penanaman nilai-nilai multikulturalisme, media penyampaian pesan-pesan agama yang damai serta penebaran cinta pada kemanusiaan. Ini yang amat dibutuhkan saat sekarang ini dalam upaya mewujudkan visi kedamaian dan kebangsaan di negeri ini.

Meskipun mereka berbeda secara identitas di mana IAIN dicirikan dengan kampus Islam, sementara IAKN kental dengan simbol Kristen. Namun, antara IAIN Ambon dan IAKN Ambon memiliki aksi nyata yang sama dalam menjaga toleransi sosial dan moderasi beragama. Dalam banyak hal, keduanya aktif melakukan advokasi-advokasi bagi warga terutama penguatan pendidikan multikultural dengan mendorong pentingnya bersikap toleran, terbuka dan menghargai perbedaan terutama perbedaan agama (Muis 2020).

Kegiatan yang paling nyata di ranah ini adalah kedua kampus ini secara aktif bekerjasama menyelenggarakan diskusi seputar pluralisme, mengadakan sekolah multikultiralisme dan pendampingan masyarakat lainnya (Administrator 2019) . Keduanya tidak hanya menyasar para pemuda dan mahasiswa, tetapi juga memberi ruang bagi para guru lintas agama dan masyarakat luas untuk mengikuti kegiatan tersebut. Tidak cukup sampai di situ, para civitas akademika yang tergabung dalam ARMC maupun PsbA juga melakukan pendampingan dan pembimbingan kepada masyarakat luas tentang pentingnya merawat keharmonian dalam keberbedaan.

IAIN Ambon dan IAKN Ambon telah memandang penting untuk mengambil peran dalam pembangunan perdamaian, di mana peran tersebut berkolerasi kuat dengan gagasan toleransi dan moderasi. 
Hasbollah Toisuta paling tidak menyebutkan beberapa peran IAIN Ambon dalam pembangunan perdamaian dan hal itu juga dilakukan oleh IAKN Ambon, yaitu (1) Meletakkan proses akademik pada semangat integrasi keilmuan, keislaman/kekristenan, kemanusiaan, sains dan budaya dan teknologi yang berbasiskan pada kesadaran multikultural. (2) Mendirikan Pusat Studi Mediasi dan rekonsiliasi di IAIN Ambon atau Pusat Studi antar Budaya dan Agama di IAKN Ambon. (3) IAIN Ambon dan IAKN Ambon juga aktif dalam proses penelitian dan pengabdian berbasis penguatan visi multikultural. (4) Mendesain kurikulum dengan memboboti kurikulum yang mewajibkan para mahasiswa untuk mengambil mata kuliah multikultural atau lekat dengan bagaimana mengelola keberagaman. (5) Mentransformasikan budaya pela dan gandong lintas negeri (desa) menjadi lintas kampus sebagai media perjumpaan lintas agama. (6) Merintis berbagai kerjasama lintas sektoral dengan berbagai elemen masyarakat.

Dari sini kita memahami bahwa para stakeholder di kedua kampus ini demikian memahami bahwa yang diperlukan sesungguhnya bukan hanya sikap toleransi sosial, melainkan juga praktik riil moderasi beragama. Yaitu, seorang individu atau kelompok masyarakat dituntut mengedepankan keseimbangan dalam hal keyakinan, moral, dan watak, baik ketika memperlakukan orang lain sebagai individu, maupun ketika berhadapan dengan institusi negara dalam perikehidupan masyarakat (Tim 2019a). Kedua kampus ini telah mengarahkan masyarakat Ambon agar mengedepankan cara pandang, sikap, dan perilaku yang selalu mengambil posisi di tengah-tengah dalam bertindak dan tidak ekstrem dalam beragama. Inilah esensi toleransi sosial dan moderasi beragama, 
yaitu menyeimbangkan kebaikan yang berhubungan dengan Tuhan dengan kemaslahatan yang bersifat sosial kemasyarakatan (Tim 2019b).

Prinsip utama yang dikembangkan ialah mendorong terciptanya suatu masyarakat beragama yang harmoni dan menghormati kemajemukan. IAIN Ambon dan IANK Ambon di lingkup kehidupan masyarakat luas, senantiasa menekankan gagasan pengetahuan agama model multireligius dan interreligious, bukan monoreligius, sehingga setiap elemen warga Ambon yang berbeda keyakinan ini akan menampilkan karakter yang inklusif. Tidak cukup sampai di situ, keduanya juga berupaya meningkatkan kesadaran akan pentingnya rasa persaudaraan, saling bertoleransi terhadap perbedaan, saling menghormati terhadap keragaman, sehingga masyarakat benar-benar bisa terhindar dari gesekan sosial yang selama ini menjadi ancaman bersama.

Pilar-pilar di atas merupakan peran stategis yang dilakukan oleh IAIN Ambon dan IAKN Ambon. Mereka berpegang pada prinsip bahwa masyarakat Maluku adalah satu kesatuan yang tidak terpisahkan. Langkah-langkah di atas semakin kuat lantaran kolaborasi yang selama ini diteguhkan kian mengakar kuat. Berdasarkan hasil wawancara dengan salah satu pengurus PsbA IAKN Ambon bahwa peluang-peluang ini akan terus diwujudkan sebab; pertama kedua kampus ini aktif menjalin kerja sama secara berkesinambungan sehingga dialog-dialog keagamaan terbuka lebar dilaksanakan bersama. Tidak hanya di ruang kampus, tetapi juga di luar lembaga. Kedua, Kedua kampus ini berkomitmen menambah pemahaman keagamaan multikultural bagi masyarakat Ambon secara luas. Ini dibuktikan dengan berbagai kerjasama yang telah dilakukan antara IAIN Ambon dan IAKN Ambon dalam upaya mengkampanyekan harmoni dalam keberbedaan di lingkup masyarakat luas. Ketiga, 
mahasiswa dari dua kampus dan lintas agama turut serta mensosialisasikan pentingnya toleransi sosial dan moderasi beragama di kota ini.

Implementasi dalam merawat nilai toleransi dan moderasi beragama tersebut, menjadi solusi nyata dalam mengurai konflik dan disharmoni yang terjadi di dalam masyarakat sebagai efek dari kemajemukan dan pluralitas masyarakat di Maluku. Pada tingkatan tertentu, keseluruhan program yang ditawarkan tersebut cukup efektif menjaga kerukunan sosial antarumat beragama di kota ini, suatu kawasan yang sesungguhnya belum benar-benar bisa dikatakan steril terhadap kemungkinan bersemainya kembali konflik-konflik bernuansa keagamaan.

Inilah peran-peran yang perlu terus disemaikan di seluruh lembaga pendidikan dalam upaya menjawab peluang dan tantangan untuk mewujudkan kebersamaan sosial. Lembaga pendidikan tinggi perlu terus mendorong masyarakat untuk menjadikan perbedaan bukan sebagai penghalang untuk berbaur dan menghormati satu sama lain, tetapi dipahami sebagai keniscayaan Ilahi yang tetap dihormati dan dijunjung tinggi atas dasar persatuan untuk menciptakan harmoni sosial dalam kehidupan masyarakat. Oleh karena itu, setiap kita perlu memberi ruang untuk menghormati keberagamaan orang lain, berlaku adil kepada orang lain, menciptakan kehidupan yang damai, serta saling mendukung dan saling menghormati dalam lingkup kehidupan masyarakat luas.

\section{Kesimpulan}

Toleransi dan moderasi di Ambon Maluku sesungguhnya telah tumbuh secara perlahan dalam masyarakat. Pasca konflik, masyarakat telah membangun relasi kuat di antara pemeluk agama-agama dengan 
membangun kesadaran kolektif berdasar pada keyakinan masing-masing. Apa yang telah dilakukan oleh IAIN Ambon dan IAKN Ambon sesungguhnya merupakan jalan untuk semakin meneguhkan toleransi sosial dan moderasi beragama tersebut. Namun disadari bahwa peranperan sosialnya selama ini telah menjadi salah satu pilar yang menopang pondasi keberagaman (religiusitas) melalui bina damai yang terus digalakkan. Ia tidak dapat dipungkiri bahwa keberadaannya di kota Ambon pada khususnya dan provinsi Maluku pada umumnya, memiliki peran strategis membangun integrasi sosial masyarakat. Bahwa keduanya dalam banyak hal telah menjadi jembatan untuk meretas perbedaan dan antagonisme di dalam masyarakat. Itu dikuatkan dengam berbagai program yang dicetuskan oleh kedua institusi ini yang telah membawa masyarakat pada arah perdamaian dan semangat kolektifitas.

Keduanya bertolak dari kebutuhan pentingnya semangat kebersamaan dan komitmen kebangsaan. Hal ini yang mendorong semakin kuatnya reintegrasi masyarakat Ambon pasca konflik bernuansa identitas agama. Untuk itulah upaya yang dilakukan oleh kedua institusi ini telah meneguhkan toleransi sosial dan moderasi beragama, yaitu menyadarkan masyarakat akan pentingnya bersikap saling toleran, menghormati perbedaan suku, agama, ras, etnis dan budaya masyarakat sebagai sesama anak bangsa yang multikultural. Kedua lembaga tersebut telah menunjukkan kepada kita bahwa yang diperlukan saat ini adalah senantiasa mengisi ruang-ruang publik dengan narasi toleransi dan moderasi yang diikuti dengan tindakan riil tentang penghargaan terhadap kemajemukan terutama dalam hal keragaman agama. Peran-peran tersebut muaranya adalah menguatkan lagi agenda kebersamaan sosial 
masyarakat Indonesia dalam kerangka toleransi sosial dan moderasi beragama.

\section{Daftar Pustaka}

Administrator. 2019. "Rektor IAKN Ambon Dan Rombongan Stusi Orientasi Ke IAIN Ambon." IAIN Ambon. https://iaknambon.ac.id/postrektor_iakn_ambon_dan_rombongan_studi_orientasi_ke_iain_ambon.ht $\mathrm{ml}$.

(2) Ahnaf, M. Iqbal \& Salim, Hairus. 2017. Krisis Keistimewaan; Kekerasan Terhadap Minoritas Di Yogyakarta. Yogyakarta: CRCS UGM.

(3) Aponno, Elsina Huberta. 2017. “Budaya Lokal Maluku 'Pela Gandong' Dalam Konteks Perilaku Organisasi." Jurnal Manajemen STIE Muhammadiyah Palopo 3(1).

(4) Bakri, Hendry. 2015. "Resolusi Konflik Melalui Pendekatan Kearifan Lokal Pela Gandong Di Kota Ambon." The POLITICS: Jurnal Magister Ilmu Politik Universitas Hasanuddin 1(1): 51-60.

\section{Dinamika Kebangsan. Parepare: IAIN Parepare Nusantara Press.}

Dinamika Kebangsaan. Parepare: IAIN Parepare Nusantara Press. https://books.google.co.id/books?id=1qTdDwAAQBAJ.

(6)

Cooper, Adam. 2011. “Pengelolaan Konflik Di Indonesia - Sebuah Analisis Konflik Di Maluku, Lembaga Ilmu Pengetahuan Indonesia, Current Asia Dan the Centre for Humanitarian Dialogue." In Centre for Humanitarian Dialogue,

(7)

Ernas, Saidin. 2012. "Policy of Social Conflict Resolution: Implementation of the Malino Agreement in Maluku." Jurnal Studi Pemerintahan 3(2).

(8) Hamid, Nur Asia. 2015. Universitas Hasanuddin "The Social Relation Religious Cross Post Conflict (Case Study Of Islam And Christian Religious Traders In The Market Mardika, Village Rijali, Subdistrict Sirimau, Ambon City." Universitas Hasanuddin.

(9) Hayat, Bahrul. 2012. Mengelola Kemajemukan Umat Beragama. Jakarta Selatan: PT. Saadah Cipta Mandiri.

(10) IAKN Ambon. 2019. PSaBA IAKN Ambon Gagas Workshop Sekolah Multikulturalisme Pemuda Agama. https://www.iaknambon.ac.id/postpsaba_iakn_ambon_gagas_workshop_sekoloh_multikuluturisme_pemud a_lintas_agama.html.

(11) Ibrahim, Ruslan. 2008. "Pendidikan Multikultural: Upaya Meminimalisir Konflik Dalam Era Pluralitas Agama." El-Tarbawi Jurnal Pendidikan Islam I(1): 115-27.

(12) Ichwanuddin, Wawan. 2016. "Pola Dan Kecenderungan Studi Konflik Di Indonesia: Analisis Terhadap Studi Kekerasan Pada Kasus Aceh Dan Ambon." Jurnal Penelitian Politik 8(1): 14. 
(13) Indonesia, Tim Penyusun Kamus Besar Bahasa. 2008. "Kamus Besar Bahasa Indonesia." Jakarta: Balai Pustaka.

(14) Jubba, Hasse. 2019. Kontestasi Identitas Agama: Lokalitas Spiritual Di Indonesia. Yogyakarta: The Phinisi Press.

(15) Lindawaty, Debora Sanur. 2016. "Konflik Ambon: Kajian Terhadap Beberapa Akar Permasalahan Dan Solusinya." Jurnal Politica Dinamika Masalah Politik Dalam Negeri dan Hubungan Internasional 2(2).

(16) Mahyuddin. 2017. "The Role of Social Capital Local Community in Multicultural Society Integration Process in Polewali, West Sulawesi." In International Conference: Universal Academic Cluster (UAC -2017),March 2324 , 2017, Bangkok, Thailand, , 71.

(17) - - - 2018. "Dinamika Multikulturalisme Mahasiswa Papua Di Yogyakarta."

(18) - - - 2019a. "The Crisis of Intolerance and Primordialism in the Name Of Religion in Indonesia: A Case Study Of Pilkada DKI Jakarta at 2017." Kuriositas 12(2019): 29-30.

(19) Mahyuddin, Mahyuddin. 2019b. "Modal Sosial Dan Integrasi Sosial: Asimilasi Dan Akulturasi Budaya Masyarakat Multikultural Di Polewali Mandar, Sulawesi Barat." KURIOSITAS: Media Komunikasi Sosial dan Keagamaan 12(2): 111-22.

(20) - - - 2019c. Sosiologi Komunikasi:(Dinamika Relasi Sosial Di Dalam Era Virtualitas). Makassar: Penerbit Shofia.

(21) Mahyuddin, Mahyuddin, Ilham Ilham, and Muhammad Rusdi. 2020. "Horor Coronavirus Deseases Dan Konflik Kekerasan Masyarakat: Tinjaun Sosiologis Atas Penolakan Jenazah Pasien Covid-19." Jurnal Commercium: Kajian Masyarakat Kontemporer 3(1).

(22) Malatuny, Yakob Godlif, and S Patra Ritiauw. 2018. "Eksistensi Pela Gandong Sebagai Civic Culture Dalam Menjaga Harmonisasi Masyarakat Di Maluku." SOSIO DIDAKTIKA 5(2).

(23) Manuputty, Jacky. 2014. Carita Orang Basudara: Kisah-Kisah Perdamaian Dari Maluku. ed. Jacky dan Salampessy Zairin Manuputty. Jakarta: Pusat Studi Agama dan Demokrasi Yayasan Paramadina Jakarta.

(24) Masringor, Julia, and Besse Sugiswati. 2017. "Pela Gandong Sebagai Sarana Penyelesaian Konflik." Perspektif: Kajian Masalah Hukum dan Pembangunan 22(1): 66-79.

(25) Mualim, Mualim, Jaffary Awang, and Ibrahim Abu Bakar. 2014. "Pela Gandong Sebagai Pemangkin Toleransi Antara Muslim Dan Kristian Di Ambon (Pela Gandong as the Enhancer of Tolerance among Muslims and Christians in Ambon)." Jurnal Hadhari: An International Journal 6(1): 43-55.

(26) Muis. 2020. Wawancara. Ambon.

(27) Mujahidin, Akhmad. 2019. “Implementasi Moderasi Beragama Di Lingkungan PTKIN." In Moderasi Beragama Dari Indonesia Untuk Dunia, Yogyakarta: LKiS Yogyakarta, 41-66. 
(28) Ode, Samsul. 2015. “Budaya Lokal Sebagai Media Resolusi Dan Pengendalian Konflik Di Provinsi Maluku (Kajian,Tantangan Dan Revitalisasi Budaya Pela)." Politika 6(2): 93-100.

(29) Pamungkas, Cahyo. 2014. "Agama, Etnisitas, Dan Perubahan Politik Di Maluku: Refleksi Teoretik Dan Historis." Masyarakat Indonesia 40: 37-56.

(30) Rengganiasih, Wilis. 2009. "Tantangan Dan Prospek Pluralisme Dalam Masyarakat Buddhis." In Prospek Pluralisme Agama Di Indonesia: Harapan Untuk Perdamaian Dan Keutuhan Ciptaan Di Indonesia, ed. Mety Herry \& Anwar Khairul. Yogyakarta: Institut Dian/Interfidei.

(31) Saidurrahman. 2019. "Penguatan Moderasi Islam Indonesia Dan Peran PTKIN." In Moderasi Beragama Dari Indonesia Untuk Dunia, Yogyakarta: LKiS Yogyakarta, 15-40.

(32) Soplanit, Jhon. 2019. "BPS: Indeks Kebahagiaan Di Maluku Subjektif." AntaraMaluku.

https://ambon.antaranews.com/berita/27373/bps-indeks-kebahagiaan-dimaluku-subjektif.

(33) Suharto, Babun. 2019. "Moderasi Beragama Dan Masa Depan Tradisi Keilmuan Perguruan Tinggi Keagamaan Islam Indonesia." In Moderasi Beragama Dari Indonesia Untuk Dunia, Yogyakarta: LKiS Yogyakarta, 1-14.

(34) Susan, Novri. 2009. Sosiologi Konflik \& Isu-Isu Konflik Kontemporer. Kencana Prenada Media Group.

(35) Susanto, Adi et al. 2020. Biografi Tokoh-Tokoh Sosiologi Klasik Sampai Postmodern. Parepare: IAIN Parepare Nusantara Press.

(36) Tim, Penyusun Kementerian Agama. 2019a. "Moderasi Beragama." In Jakarta: Badan Litbang dan Diklat Kementerian Agama RI. (37) - - - 2019b. Tanya Jawab Moderasi Beragama. Jakarta: badan Litbang dan Diklat Kemenag RI.

(38) Toisuta, Hasbollah. 2019. "Beragama Dalam Masyarakat Multikultural." In Moderasi Beragama Dari Indonesia Untuk Dunia, Yogyakarta: LKiS Yogyakarta. 